\title{
Distributed Donne: A Response to the Problem of His Titles
}

JANIS

LULL

Summary: Most of the titles traditionally associated with Donne's poems probably did not originate with the biographical Donne. When modern editors use these titles, they expand Donne's authorial "self" to include the literary judgments of the poet's first readers as well as their own literary judgments. Assimilating such non-authorial choices to the selfof the author has two things to recommend it: it is consistent with the practices of the interactive literary subculture to which Donne chose to belong, and it offers an alternative for those who can no longer believe in intentionalism as the only principle of editorial choice.

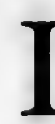

In a reaction against the author-centered assumptions of the New Bibliography, textual critics have lately stressed the social construction of literature. Jerome McGann, a leading proponent of what some (although not McGann) call the "social theory of editing," claims as an "overriding fact" about literary texts that they "are produced and reproduced under specific social and institutional conditions, and hence that every text, including those that may appear to be purely private, is a social text."1 According to McGann, the concept of the author's final intentions, the traditional target of scholarly editing, "is itself ambiguous and unstable," and also "misrepresents the interactive procedures by which texts are constituted."'

Recent scholarship in English Renaissance literature, especially in the textual criticism of Shakespeare, tends to support the assertion that literary texts often result from the interaction of agents. ${ }^{3}$ Like Shakespeare's plays, John Donne's poems have come under scrutiny as examples of literature 
produced by social interaction. Leaving aside the question of whether McGann's interactive theory applies to all literary works, it seems clear that the texts of Donne's lyrics, like the texts of Shakespeare's plays, require editors to take account of more than the intentions - however defined - of an isolated individual. As Ted-Larry Pebworth has pointed out, modern editors of Donne's poems must deal with more than 250 known manuscripts, none of them in the poet's hand, as well as with a history of transmission in which non-autorial alterations of the texts were not necessarily regarded as corruptions. ${ }^{4}$ Yet even in the face of such a history, Pebworth maintains that "the job of the textual editor" is to attempt to recover authorial texts and "thus make possible the delineation of individual talent." 5

In the case of Donne's titles, an editor's search for an "individual talent" may prove futile unless we are willing to let the "individual" be more than one biological person. The titles associated with Donne's poems from the earliest printed editions have helped create what modern readers think of as the poet's characteristic "metaphysical" style. Yet as both Helen Gardner and John Shawcross have stressed, most of these titles probably did not originate with the biographical Donne. ${ }^{6}$ As Gardner says, "It may be that Donne himself did anticipate Herbert in realising that a title could be more than an identifying device or description of a poem's content, but perhaps this praise ought to go to the unknown compiler of the collection of his poems preserved in one group of manuscripts" (the cluster labeled "Group II" by Donne's Oxford editors). ${ }^{7}$ In addition to the Group II compiler, the editors of 1633 and 1635 should also get credit for creating some of Donne's titles. Nor should we exclude the compilers of other manuscripts, who may have invented such widely accepted titles as "The Funerall," "The Blossome," and "The Primrose." Whoever was responsible for Donne's titles, however, they may still be called "Donne's" if we allow "Donne" to be distributed over more territory than that contained inside his actual skin.

The idea of the distributed self, as the psychologist Jerome Bruner points out, has gained currency in a wide variety of disciplines during the second half of the twentieth century. ${ }^{8}$ Our modern preoccupation with self and personhood has taught us, as Bruner puts it, that

a person's knowledge is not just in one's own head, in 'person solo,' but in the notes that one has put into accessible notebooks, in the books with underlined passages on one's shelves, in the handbooks one has learned how to consult, in the information sources one has hitched up to the computer, in the friends one can call up to get a reference or a 'steer,' and so on almost endlessly.' 
This expanded notion of selfhood contrasts with the traditional Western concept of self described by anthropologist Clifford Geertz: "a bounded, unique, more or less integrated motivational and cognitive universe, a dynamic center of awareness, emotion, judgment, and action organized into a distinctive whole and set contrastively both against other such wholes and against a social and natural background."10 Such an individualized concept of personhood, however, as Geertz's own work has shown, stands out as "a rather peculiar idea within the context of the world's cultures." ${ }^{11}$ Even the highly individualized Western self, according to Bruner, may best be described not as a nucleus of subjectivity but as "a product of the situations in which it operates."12

What we now read as Donne's poetic self was similarly distributed over many sources and resources. In 1614, for example, Donne wrote to his friend Sir Henry Goodyer, saying that he felt pressed to publish his poems and asking "to borrow that old book of you" to serve as the basis of a possible print edition. "By this occasion," Donne wrote, "I am made a Rhapsoder of mine own rags, and that cost me more diligence, to seek them, than it did to make them."'13 Although Donne clearly regarded his work as his own to revise or to publish, he evidently did not think it necessary to keep copies in his possession, trusting the texts entirely to his friends. Even in his own lifetime, his poems belonged to an extended network of texts, not just to his own consciousness or person.

The remains of this manuscript network and the early print editions supply the only textual sources for Donne's titles. "The broken heart," for instance, seems to have originated with the first edition of 1633 . "The Baite" comes from the second edition (1635). Many other titles - "The Anniversarie," "Womans constancy," "Loves growth," "The Expiration," "A Valediction forbidding mourning," "The Prohibition," "The Sunne Rising," and others - appear only or mainly in the Group II manuscripts. ${ }^{14}$ While acknowledging that Donne probably did not write the traditional titles, Gardner regards them as "a great convenience"15 and uses them in her edition of The Elegies and the Songs and Sonnets. ${ }^{16}$ Shawcross fears misreadings, and urges his fellow scholars to "discourage continued use of a non-Donnean title." ${ }^{17}$ His identification of "non-Donnean" titles, however, turns mostly on literary judgment. He assumes, for example, that a poet of Donne's ingenuity would not use a heading such as "To His Mistress Going to Bed" or "Going to Bed" because so many other poems of the period have similar or identical titles. ${ }^{18} \mathrm{But}$ it seems extreme to say that the literary personality we know as "Donne" would never have chosen a conventional title. Even the biographical Donne may have liked one once in a while. Few have doubted that Shakespeare, another highly ingenious 
poet, chose the names of such plays as Twelfth Night, As You Like It, or Much Ado About Nothing. The point is not that Shawcross as an editor or textual critic should refrain from using literary judgment in constructing an authorial self for Donne, but that editors need to acknowledge such judgment and the role it often plays in creating what later readers take to be the poet's own work.

Perhaps Gardner and Shawcross would have agreed that "Donne's" titles are best seen not as the creations of a single individual but as the products of a particular social context, the manuscript-based literary subculture that coexisted with print in the seventeenth century. ${ }^{19}$ Some of Donne's fellow poets, Ben Jonson, for example, or George Herbert, evidently shared the modern assumption that a poet's job includes preparing a definitive authorial. text for the press. Donne apparently subscribed to the older tradition, in which poems were circulated only in manuscript and perhaps never existed in a single authorized version. This manuscript tradition encouraged a degree of exchange between poet and reader that sometimes amounted to multiple authorship. In medieval manuscript culture, as Mary Carruthers has recently demonstrated again, being respected as an "author" often entailed attracting written commentary in the margins of one's work. ${ }^{20}$ In some cases the writer might respond to the commentary, the entire exchange then becoming part of future copies of the manuscript. ${ }^{21}$ Donne, who could have published his poems, chose manuscript circulation instead, with the implication that he also chose the intimate textual association with his readers that belongs to the manuscript tradition. As a result, the poet "Donne" - his authorial personality, his poetic choices - became closely identified with the responses of his contemporaries. ${ }^{22}$

This association of Donne's authorial persona with the cultural context of his poems means that modern editors cannot easily dismiss titles that originated in manuscripts and miscellanies and even in the early editions. Whether or not Donne "himself" endorsed these titles, they may be taken as authorized by the textual culture to which Donne chose to belong. Circulating his poems to a select group not only showed Donne's faith in the literary judgments of his contemporaries, but also insured that his contemporaries' editorial decisions would help determine his poetic reputation. In this way Donne has come down to us as he chose to appear in his own time - as a distributed poetic self.

An expanded sense of Donne's authorial self may oblige readers to think of stock headings such as "Song" and "Going to Bed" as "Donne's" titles, but it also lets us credit him with the "witty," "metaphysical" kind of title that has helped define a style and an era. The title of "The broken heart," for example, 
like Herbert's "Church-lock and Key," captures a metaphor that informs the whole poem, not just its ending. This title identifies a governing conceit that the poem does not even suggest until the end of the third stanza: "Love, alas, / At one first blow did shiver it as glasse" (23-24). This poem is untitled in the majority of Donne's manuscripts. In others it is headed "Song," "Canzone," "Elegie," "Against Love," and once, for a portion of the poem, "A Description of ye hart, or rather loue in it." 23 Of all these titles, only "The broken heart" alludes to the emblem developed in the poem's last stanzas, which pictures the heart in pieces in the speaker's breast, capable still of fragmentary emotions, but no longer capable of feeling a complete love: "My ragges of heart can like, wish, and adore, / But after one such love, can love no more" (31-32).

"Not bad," says Shawcross of this title, "but not Donne." ${ }^{24}$ Most likely the historical Donne did not create the familiar title of "The broken heart," since it first appeared in the edition of 1633, the year Donne died. Following the established practices of the manuscript culture, Donne's first editor apparently felt free to create titles, just as manuscript compilers did before 1633 and other editors have since. (Gardner, for example, creates several titles, including "Recusancy," "Tutelage," and "Image and Dream.") ${ }^{25}$ Neither the manuscripts nor the early print editions show for certain what the biographical Donne would have wanted, but they do show that emblematic titles such as "The broken heart" formed part of the poetic climate in which Donne lived.

"The Baite" is another such title, evidently provided by the editor of 1635 , who also seems to have given us "Communitie," "The Message," "Confined Love," and "The undertaking." As Gardner points out, this editor may have had access to some independent source of information about the poems. To the title of "The Primrose," for example, this edition adds, "being at Mountgomery Castle upon the hill, on which it is situate." ${ }^{26}$ Like this explanatory expansion added to "The Primrose," the title of "The Baite" helps locate its poem, this time not in a geographical context, but in the context of Marlowe's "The Passionate Shepherd to His Love," to which Donne's poem is an answer. In Marlowe's poem, the Shepherd gracefully offers love inducements to his beloved: "And I will make thee beds of Roses/ And a thousand fragrant posies, I A cap of flowers, and a kirtle / Imbroydred all with leaves of Mirtle" (9-12), and so on. ${ }^{27}$.At last, the Shepherd sums up his argument: "And if these pleasures may thee move, / Come live with mee, and be my love" (19-20).

Donne's point, in his parody of Marlowe, is that the male speaker, in setting his pastoral bait for the woman, is really hooking himself. Donne imagines vividly the erotic pastoral pleasures that Marlowe only hints at as he 
dresses his Shepherdess in leafy kirtle, and "belt of straw, and Ivie buds, / With Corall clasps and Amber studs" (17-18). Donne's speaker, by contrast, undresses the woman and envisions her swimming among the enamored country fishes, to which he compares himself in the poem's last lines: "That fish, that is not catch'd thereby, / Alas, is wiser farre then I" (27-28). Shawcross attacks "The Baite" as a title for this poem because it "suggests that the woman is aware that she is the bait to catch this poor fish of a lover, which she isn't, and that the fisher, illogically, is using the bait to catch himself. ${ }^{.28}$ But this title by itself does not particularly imply that the woman is aware of her seductiveness, although the poem aims to make her aware. In several late miscellanies the poem bears headings such as "An invitation of his Mrs to come and fish," suggesting that the compilers recognized the poem's efforts to make the woman conscious of her sexual powers. ${ }^{29}$ As for the "illogic" of the speaker's catching himself, this is exactly the point of the poem.

Like "The broken heart" and "The Baite," titles that apparently originated with Donne's early print editors, many of the manuscript titles - usually from Group II - turn out to be wittily appropriate to their poems. "The Anniversarie," "Loves growth," and "The Expiration," for instance, resemble such Herbert titles as "Paradise" in their use of summary nouns - mentioned nowhere in the poem - to encapsulate content. "The Anniversarie" enhances Donne's paradox of the yearly return that is truly a new beginning only for the lovers: "All other things, to their destruction draw, / Only our love hath no decay" (67). Similarly, the title of "Loves growth" captures the abstract idea that informs the whole lyric, including its inspired final comparison of love in the spring to swelling taxes: "And though each spring doe adde to love new heate, / As princes doe in times of action get / New taxes, and remit them not in peace, / No winter shall abate the springs encrease" (25-28). This same quality of deft summarizing caused Gardner to regard "The Expiration," as "a title of genius" for a lyric whose unifying analogy is the connection of breath and death.$^{30}$ The first half of the poem represents an intake of breath, turning on the conceit of a farewell kiss that "sucks two soules, and vapors both away"(2). In the second half, the speaker breathes out, uttering the single destructive syllable, "goe," and thereby setting in motion the "expiration" of love. Whether the title of "The Expiration" was the work of the compiler, the poet, or someone else, both the author and later readers have been well served by this particular heading.

"Womans constancy," on the other hand, is an ironic title, more like Herbert's "Deniall" in that it does not summarize the entire argument of the poem but leaves a surprise twist at the end to be discovered by the reader. In 
this case the irony is that the male speaker of the poem is at least as likely to prove inconstant as the woman: "against these scapes I could / Dispute, and conquer, if I would, / Which I abstaine to doe, / For by to morrow, I may thinke so too." "The Sunne Rising," one of the best-known of all Donne's titles, also lends an ironic touch to its lyric, emphasizing both the poem's challenging tone and the ultimate futility of the challenge. The speaker asserts the power and importance of his love against the powers of the sun, whose job is to keep time and to "warme the world." As the sun rises, so does the human voice that seeks to arrest time and contract the world into a bedroom. Like some of Donne's other challenge-poems - "Death be not pround," for example - this one is brave try, but finally not completely convincing. Most readers find it easier to believe Marvell's "though we cannot make our Sun / Stand still, yet we will make him run" (45-46) than Donne's "This bed thy center is, these walls, thy spheare" (30). "The Sunne Rising" as a title suggests from the outset that the sunrise bravado evoked in the poem cannot really last, any more than the hour of sunrise can. The sun, in spite of poetic persuasion, will set tonight and rise again tomorrow, creating "houres, dayes, moneths, which are the rags of time" (10) and the enemies of love.

Not all Group II titles are so appealing. The word "forbidding". in "A Valediction forbidding mourning," as Shawcross notes, may suggest an unpleasantly authoritarian attitude toward the beloved. ${ }^{32}$ But if the word had such overtones in Donne's time, clearly the poetic culture around him endorsed the implications, or we would not have the title at all. Perhaps the biographical Donne would have endorsed them as well. The speaker of "The Prohibition" warns his lover to remember that he "forbade" her to love him. The actual words of that forbidding," however, are "Take heed of loving mee" (1) suggesting that perhaps the poet thought of "forbidding" or even "prohibiting" as less dictatorial speech-acts than they seem to us today. The word "mourning" in this title also bothers Shawcross, because he thinks it implies "communication beyond the grave." Yet this, too, is a literary judgment open to question. To many readers - perhaps to most - "mourning" in this context suggests sorrow, grief, or regret (the first meaning given in the $O E D$ ), with no added implication that the cause of the sorrow is death.

In addition to quarreling with the appropriateness of some headings as guides to the content of Donne's poems, Shawcross also objects to several titles because they imply biographical connections that he regards as misleading. He is especially disturbed by "A Hymne to Christ, at the Authors last going into Germany," and "Twicknam Garden." Like the geographic expansion 
given to "The Primrose" in the 1635 edition, these titles direct readers to specific events or places associated with Donne's life but not mentioned in the poems. If such biographical headings did not originate with Donne, they have more power than titles like "The Expiration" or "The Sunne Rising" to skew readers' perceptions in ways the poet did not intend. As Shawcross hinself shows, however, dropping such titles from print editions will not stop scholars from drawing biographical inferences and communicating them to others, as they have in the case of "The Autumnal." This poem's supposed connection with Magdalene Herbert derives in part from titles such as "On the Lady Herbert afterwards Danvers," which appears in the Luttrell and O'Flahertie manuscripts. Although this apparently biographical information has not become part of the standard title for the poem, the association persists, fuelled by the manuscript headings and by Izaac Walton's biography. Shawcross accuses the manuscript tradition of "total insensitivity" in titling this poem, but does not make it clear why he thinks that linking the poem to Magdalene Herbert is more insensitive than any other connection..$^{33}$ Perhaps modern taste finds insensitivity in the poem itself, which dwells on the spent passions and gravelike wrinkles of a woman of fifty.

At the end of his article Shawcross proposes editorial guidelines that show how his intentionalist position softens as it moves toward practical prescription. An editor's first step in choosing titles for Donne's poems, he says, should be

to ascertain what might have been Donne's title (there may be few beyond the generic and the verse letter forms); second, to accept well-known titles if they do not conflict with the substance of the poem and are obvious possibilities (like 'The Flea'); third, a kind of combination of the two others, to employ a well-known title that might have been Donne's but without whatever questionable additions might have accrued (like 'A Valediction'); and fourth, to omit titles and give only a short form of the first line. ${ }^{34}$

Following these guidelines, an editor could keep many titles that probably did not originate with Donne if, in the editor's judgment, they were "obvious possibilities" and did not "conflict with the substance of the poem." For some editors, the obvious possibilities would not include "The Baite" or "A Valediction forbidding mourning," but for others they would. One editor might consider Donne "insensitive" to write a poem about the wrinkles of a woman only five years his senior, while another might not.

In short, an editor who followed Shawcross's intentionalist guidelines might end up with titles that differed.very little from those selected by one who 
believed with McGann that an author's intentions should not be the only standard by which editorial choices are made. Without new evidence, neither editor would be able to say which titles, if any, Donne intended to give his poems. The main difference would be that the intentionalist editor would try to explain title choices by talking only about what Donne might have wanted or about what the poem seems to want, while the editor oriented to social interaction would be free to bring in facts both about Donne's literary environment and about the modern literary environment in which the editing takes place.

The intentionalist approach produces choices that must be justified by how closely they approach the traditional goal of scholarly editing - to reconstruct, insofar as possible, what the author would have wanted. Editions of Donne's poems based on this goal tend to de-emphasize the many intermediaries who stand between Donne and his modern audience, and thus to allow the titles to signify the sames kinds of authorial gestures as the titles of a poet like Jonson, who prepared his own work for publication. Nor would dropping all titles or substituting shortened first lines solve the problem. An edition that omitted titles but continued to rely entirely on intentionalist assumptions would imply by those very assumptions that Donne must have wanted his poems to have no titles, and this seems even less likely than the implication left by the older editions that he wanted them to have the titles they have now. ${ }^{35}$

The interactionist approach, on the other hand, would acknowledge that Donne's authorial self grows out of different circumstances than those of other poets and may demand different ways of reading. The interactionist editor might follow the intentionalists in using titles that reflect neither the known choices of the author nor the majority of the manuscripts - "Loves growth" rather than "Spring," "The Expiration" instead of "Valediction" or a Latinized equivalent, "The Sunne Rising" rather than "Ad Solem." Unlike earlier editors, however, the interactionist would emphasize that choosing these titles constitutes an expansion of Donne's authorial persona to include the literary judgments of some of the poet's friends and earliest readers as well as those of the editor. It is hard to tell how modern readers would deal with the traditional titles if they appeared in an edition where the transmission history of the poems and the literary views of the editor became part of the conceptual justification for the text instead of remaining coded and dormant in the scholarly apparatus at the bottom of the page. In spite of the theorizing of interactionists like McGann, we have little experience of such an edition. Literary editing remains a conservative activity, and editors who depart too radically from accepted 
practice run the risk of alienating their audience.

It may be that reading practices will have to change before editing practices can. Such changes are already at work in the case of "Shakespeare," a word that now signifies to some readers the name of a biographical individual and his artistic environment rather than of the individual alone. Perhaps "Donne" - the author of "The Baite," "The broken heart," and "A Valediction forbidding mourning" - could be reconceived along the lines of this newly distributed "Shakespeare." Such a shift in perception might mean that readers would want separate editions of important manuscript collections of Donne's poems. It might also create a demand for eclectic editions aimed more at representing a tradition than an individual talent. Either option could involve an editor's explicitly selecting non-Donnean titles, thereby recognizing that the authorial persona represented in the edition extends beyond the biographical author. Such an editorial procedure has two things to recommend it. It is consistent with the practices of the interactive literary subculture to which Donne chose to belong, and it offers an alternative for editors and readers who can no longer believe in pure intentionalism. When we explain Donne's authorial personality in part by pointing to his witty, "metaphysical" titles and then acknowledge that many readers over several centuries have shared responsibility for those titles, we also acknowledge openly that Donne, or at least Distributed Donne, is partly us.

University of Alaska, Fairbanks

\section{Notes}

1. Jerome J.McGann, "Literary Pragmatics and the Editorial Horizon," The Textual Condition (Princeton: Princeton University Press, 1991), p. 21. In an exchange with McGann in Text, T. H. Howard-Hill calls McGann's position "the social theory of editing." McGann's response pointedly refers to "my so-called Social Theory of Editing." See T. H. HowardHill, "Theory and Praxis in the Social Approach to Editing," Text: Transactions of the Society for Textual Scholarship, 5 (1991), 31-46; and Jerome J. McGann, "Response to T. H. Howard-Hill," 47-48.

2. McGann, "What is Critical Editing," The Textual Condition, p. 67. The phrase "final intentions," traditional in textual scholarship, has found some theoretical grounding in the work of Michael Hancher, whose "Three Kinds of Intention" was adopted by G. Thomas Tanselle in "The Problem of Final Authorial Intention," Studies in Bibliography, 29 (1976), 167-211. According to Tanselle, Hancher's "active intention" - the author's intention that a completed text should be understood in certain ways - comes closest to the kind of authorial intention sought by scholarly editors. Even editors devoted to intentionalism do not necessarily agree, however, that authorial intention coincides with the writer's inten- 
tions for the completed text. See especially Hershel Parker, Flawed Texts and Verbal Icons: Literary Authority in American Fiction (Evanston: Northwestern University Press, 1984).

3. On textual criticism and the interactive drama of the English Renaissance, see, among others, Stephen Orgel, "What is a Text?" Research Opportunities in Renaissance Drama, 24 (1981), 3-6; and Paul Werstine, "Narratives about Printed Shakespeare Texts: 'Foul Papers' and 'Bad' Quartos," Shakespeare Quarterly, 41 (1990), 65-86.

4. Ted-Larry Pebworth, "Manuscript Poems and Print Assumptions: Donne and His Modern editors," John Donne Journal, 3 (1984), 1-21.

5. Ted-Larry Pebworth, "John Donne, Coterie poetry, and the Text as Performance," Studies in English Literature, 29 (1989), p. 71.

6. See Helen Gardner, "The Titles of Donne's Poems," Friendship's Garland: Essays Presented to Mario Praz, ed. Vittorio Gabrieli (Rome: Edizioni di Storia e Letteratura, 1966), 189-207; and John T. Shawcross, "But Is It Donne's? The Problem of Titles on His Poems," John Donne Journal, 7 (1988), 141-149.

7. Gardner, "Titles," p. 207.

8. Jerome Bruner, Acts of Meaning (Cambridge: Harvard University Press, 1990), p. 107.

9. Bruner, p. 106.

10. See Clifford Geertz, "From the Native's Point of View: On the Nature of Anthropological Understanding," Interpretive Social Science: A Reader, ed. Paul Rabinow and William M. Sullivan(Berkeley: University of California Press, 1979), p. 229. The intentionalist position in textual criticism depends on this traditional Western concept of self. Howard-Hill, for example, postulates an authorial activity he calls "composition," as distinguished from the interactive process of text production described by McGann: "By composition I mean the authorial production of a text, a form of words intended to exclude an author's mental interaction with social or literary influences or anticipations of reception as interactive activities" (p. 35). Howard-Hill thus identifies authorial intention with an extreme version of the autonomous self. The writer somehow writes without interacting even mentally with the social systems of language, literature, and reception.

11. Geertz, p. 229.

12. Bruner, p. 109.

13. Helen Gardner and Timothy Healy, eds. John Donne: Selected Prose (Oxford: Clarendon Press, 1967), pp. 144-145.

14. The titles and texts of Donne's poems are cited from John T. Shawcross, ed. The Complete Poetry of John Donne (New York: New York University Press, 1968).

15. Gardner," "Titles," p. 207.

16. Helen Gardner, ed. John Donne: The Elegies and The Songs and Sonnets (Oxford: Clarendon Press, 1965).

17. Shawcross, "Is It Donne's," pp. 148-149. 
18. Shawcross, "Is It Donne's," pp. 144-145.

19. On the manuscript subculture, see, in addition to Pebworth, J. W. Saunders, "The Stigma of Print: A Note on the Social Basis of Tudor Poetry," Essays in Criticism, 1 (1951), 139164; Arthur F. Marotti, "John Donne and the Rewards of Patronage," Patronage in the Renaissance, ed. Guy Fitch Lytle and Stephen Orgel (Princeton: Princeton University Press, 1982), 207-234; and Marotti, John Donne, Coterie Poet (Madison: University of Wisconsin Press, 1986).

20. See Mary Carruthers, The Book of Memory: A Study of Memory in Medieval Culture (Cambridge: Cambridge University Press, 1990), pp. 217-218. Walter J. Ong also points out the dialogic character of the manuscript culture in his Orality and Literacy: The Technologizing of the Word (New York: Methuen, 1982), p. 132.

21. Carruthers, p. 212.

22. Against assertions that Donne lacked the print author's interest in "controlling his work, Richard B. Wollman argues that Donne's choice of the more intimate manuscript subculture allowed him to limit misinterpretations of his poems by limiting circulation to readers he trusted. See "The 'Press and the Fire': Print and Manuscript Culture in Donne's Circle," Studies in English Literature, 33 (1993), 85-97.

23. For the headings of Donne's poems in manuscript, see Peter Beal, ed. Index of English Literary Manuscripts, vol. 1, part 1 (New York: R. R. Bowker, 1980), 243-555.

24. Shawcross, "Is It Donne's," p. 147.

25. Gardner, Elegies and Songs and Sonnets, pp. 10, 12, and 58.

26. Gardner, Elegies and Songs and Sonnets, p. 88.

27. Cited from Fredson Bowers, ed. The Complete Works of Christopher Marlowe, vol. 2 (Cambridge: Cambridge University Press, 1981), p. 537.

28. Shawcross, "Is It Donne's,", pp. 147-148.

29. See Beal, p. 284.

30. Gardner, "Titles," p. 206.

31. These lines from "To his Coy Mistress" are cited from The Poems and Letters of Andrew Marvell, ed. H. M. Margoliouth, 3rd ed., revised by Pierre Legouis and E. E. Duncan-Jones (Oxford: Clarendon Press, 1971), p. 28.

32. Shawcross, "Is It Donne's," p. 148.

33. Shawcross, "Is It Donne's," p. 145.

34. Shawcross, “Is It Donne's," p. 148.

35. Shawcross says, "I suppose it is to be presumed that Donne gave a title to most of his poems, if not all. I suppose it can be presumed that some of the titles we have were his, or based on his," but offers no arguments for these suppositions ("Is It Donne's," p. 143). 